\title{
BARRIERS IN EDUCATION OF MANAGERS IN INFORMATION-COMMUNICATION TECHNOLOGIES
}

Vladimír BOLEK*, Ekonomická univerzita v Bratislave, Slovenská republika Andrea KUBIŇANOVÁ

Přijato: 6. 7. 2017 / Akceptováno: 13. 9. 2017

Typ článku: Výskumná štúdia

DOI: $10.5507 /$ jtie.2017.020

Abstract: Lifelong learning has been improving and playing an important role in the education process for recent years. To meet the changing requirements of employers for current and potential employees is one of the goals. Claims on employees' knowledge and skills in the area of information and communication technologies are under continuously increasing demands. This situation asks them to increase the level of information literacy. The most effective way is lifelong education. However this education can be limited by some barriers. This article is concentrated on research's result about Identified barriers in education of managers in information and communication technologies and factors which can influence this area.

Key words: lifelong learning, information literacy, manager, barriers, skills

\section{BARIÉRY VO VZDELÁVANÍ MANAŽÉROV V INFORMAČNO-KOMUNIKAČNÝCH TECHNOLÓGIÁCH}

Abstrakt: V posledných rokoch sa celoživotné vzdelávanie dostáva do popredia a zastáva významnú rolu $v$ procese vzdelávania sa. Jedným z cielov je naplnit' meniace sa požiadavky zamestnávatel'ov kladené na aktuálnych a potenciálnych zamestnancov. Neustále zvyšujúce sa nároky na ich znalosti a zručnosti v oblasti informačno-komunikačných technológii ich nútia $k$ zvyšovaniu úrovne informačnej gramotnosti. Najefektívnejšou cestou k jej zvyšovaniu je celoživotné vzdelávanie. Avšak samotné vzdelávanie ovplyvňujú okrem iného aj viaceré bariéry. Článok prezentuje výsledky prieskumu identifikovaných bariér vo vzdelávani manažérov a faktorov ich ovplyvňujúcich $v$ oblasti informačnokomunikačných technológií.

Kl'účové slová: celoživotné vzdelávanie, informačná gramotnost', manažér, bariéry, zručnosti

*Autor pre korešpondenciu: vladimir.bolek@euba.sk 


\section{1 Úvod}

Rozvoj informačnej spoločnosti a neustále rozširovanie sa informačnokomunikačných technológií poskytujú príležitost' $\mathrm{k}$ učeniu a získavaniu nových digitálnych zručností a schopností, ktoré sa stali nevyhnutými pre zamestnanie, vzdelávanie a odbornú prípravu, osobný rozvoj a zapojenie do spoločnosti. Ako sa spoločnost' stáva stále viac spoločnost'ou založenou na vedomostiach, tak sa mení aj obsah toho, čo sa l'udia potrebujú naučit' a vediet'. IKT menia spôsob, akým l'udia pracujú, učia sa a zdokonal'ujú svoje schopnosti. Tento proces sa dotýka aj manažérov organizácií a podnikov. Je viac ako nutné uvedomit' si význam vzdelávat' sa práve v tejto oblasti, ktorá nimi často býva prehliadaná. Iba tak budú schopní napĺn̆at’ požiadavky kladené na ich znalosti v oblasti IKT a pružne reagovat' na zmeny, ktoré so sebou táto započatá digitálna éra prináša.

Článok prezentuje parciálne výsledky rozsiahleho výskumu zameraného na vzdelávanie manažérov v oblasti informačno-komunikačných technológií. Hlavným ciel'om bolo identifikovat' významnost' bariér vo vzdelávaní manažérov v informačnokomunikačných technológií. Tento hlavný ciel' naplńajú viaceré čiastkové ciele: analyzovat' teoretické východiská $\mathrm{k}$ danej problematike, realizácia prieskumu, identifikovanie bariér vo vzdelávaní, analyzovat' vplyv faktorov (vek, pohlavie) a ich štatistickú významnost' na vnímanie bariér.

Boyasitz (1982) definuje IT znalosti manažérov ako „špecializované vedomosti, užitočný súbor faktov a relevantných pojmov pre konkrétnu pracovnú pozíciu“. Na základe tejto definície, Bassellier a kol. (2001) identifikovali tri hlavné oblasti znalostí, ktorými by mali manažéri disponovat', aby boli schopní využivat' IKT vo svoj prospech a zároveň $\mathrm{v}$ prospech organizácie ako takej:

1. mat' najnovšie informácie a prehl'ad o aktuálnych aktivitách a príležitostiach v oblasti IKT,

2. pochopit' hodnotu a potenciál IT,

3. poznat' potenciál ako aj súčasné a budúce obmedzenia IT a zároveň zistit', ako IT využívajú konkurenčné spoločnosti.

Ďalšiu klasifikáciu požadovaných IT zručností zadefinovali Brown a Magill (1994). V tomto prípade autori navrhli rozdelenie riadenia na zvlášt' riadenie technológií a manažment ich aplikovanie do IS:

1. Riadenie technológií - zahŕňa počítačové operácie, komunikáciu/konektivitu, vývoj technológií a technologické plánovanie,

2. Riadenie používania technológie - zahŕňa vývoj systémov, počítačovú podporu pre koncového užívatel'a a plánovanie aplikácie.

Zároveň sa autori domnievajú, že hlavným ciel'om IT vedomostí manažérov je umožnit' manažérom efektívne komunikovat' s IT personálom. Táto znalost' ul'ahčuje „odkaz“ alebo „prepojenie“ medzi bežnými oddeleniami a oddelením IT v rámci spoločnosti. Reich a Benbasat (2000) definujú ,prepojenie“" ako stupeň, v ktorom IT poslanie, ciele a plány podporujú podnikovú misiu, ciele a plány prostredníctvom ich vzájomného zosúladenia. Títo dvaja autori uvádzajú, že pojem ,prepojenie“ má dve dimenzie: 
1. Intelektuálny rozmer - predstavujúci vnútornú konzistenciu a vonkajšiu platnost' obsahu IT a obchodných plánov,

2. Sociálny rozmer - predstavujúci vzájomné porozumenie zámerov a ciel’ov medzi vrcholovými manažérmi a manažérmi IS, resp. IT oddelenia.

Bassellier a kol. (2001) klasifikuje explicitné IT znalosti manažérov do piatich skupín:

1. Technológie - manažéri by mali disponovat' vedomostami o hardvéri a softvéri v rôznych oblastiach (spracovanie, ukladanie dát a komunikácia). To im umožní zhodnotit' existujúce IT infraštruktúry, pochopit' popis funkcií systému a formulovat' požiadavky pre budúci vývoj.

2. Aplikácie - tento bod odkazuje na znalost' bežných IS využívaných v priemysle (vertikálne aplikácie) a bežné aplikácie v rôznych organizačných funkciách, a na spôsob, akým tieto aplikácie môžu pomôct' dosiahnut' ciele spoločnosti. To zahŕňa vedomosti o portfóliu aktuálne využívaných aplikácií, informačných architektúrach a novo sa vyvíjajúcich aplikáciách.

3. Vývoj systému - pri ňom je nevyhnutné mat' znalosti o postupoch v oblasti projektového manažmentu, časového manažmentu, výpočtu rozpočtu a podobne. Taktiež manažér musí byt' zvyknutý na rôzne metodiky vývoja, životný cyklus systému, prácu s koncovým užívatel’om, nákup softvéru a outsourcing.

4. Manažment IT - manažéri musia poznat' činnosti spojené so správou IT, aj ked' sa na nej aktívne nepodielajú, pretože to im umožňuje integrovat' strategické plánovanie IT so zvyšnými aktivitami spoločnosti.

5. Prístup k IT znalostiam - nemožno očakávat', že manažér disponuje komplexnými znalost'ami IT, preto musí manažér poznat'spol'ahlivé zdroje poznatkov, a to ako vo vnútri spoločnosti, tak aj mimo organizácie, ktoré mu poskytnú odborné poradenstvo o IT.

Prvé štyri skupiny (technológie, aplikácie, vývoj systému a manažment IT) vychádzajú $\mathrm{z}$ rámca IT znalostí v programe MBA. Zároveň sa nachádzajú aj vo väčšine publikácií zaoberajúcich sa touto problematikou. Piata skupina odráža schopnost' človeka vytvárat' si tzv. „,vedomostné siete“. K vy̌šsie spomenutým piatim skupinám zároveň možno pridat’ d’alšie dve oblasti. Tieto oblasti sú prezentované vo väššine aktuálnych manuáloch a publikáciách týkajúcich sa manažmentu IS:

1. Internetové podnikanie - význam vplyvu internetu na podnikanie sa môže líšit' v závislosti od odvetvia, ale nemožno nespomenút novodobé faktory úspechu firiem akými sú napríklad mobilné technológie a nové online marketingové nástroje, ktoré ponúka rozhranie web 2:0.

2. Právne aspekty - všetky krajiny majú pravidlá a zákony na ochranu údajov, manažéri teda musia dbat' na ich dodržiavanie. Osobné údaje by mali byt' ukladané a archivované iba za splnenia prísnych podmienok. Tak isto by manažri mali poznat' právne aspekty internetového podnikania. Rast globálneho elektronického trhu ovplyvnil niekol'ko právnych otázok, vrátane zabezpečenia siete a transakcií, ochrany vlastníckych práv, správy platobných systémov, zákonnosti elektronických zmlúv a rôznych aspektov jurisdikcie v kybernetickom priestore.

Manažéri si v súčasnosti čoraz viac uvedomujú, že je potrebné neustále flexibilne reflektovat' na súčasné potreby organizácií, tak prirodzene rozširujú svoje obzory prostredníctvom celoživotného vzdelávania. Problematika celoživotného vzdelávania sa 
netýka iba okruhu manažérov, ale je to celospoločenský fenomén, ktorý je ukotvený aj v rámci stratégie celoživotného vzdelávania a celoživotného poradenstva ako nástroja formovania vedomostnej spoločnosti.

Najefektívnejšou cestou zvyšovania úrovne informačnej gramotnosti manažérov je ich neustále vzdelávanie. Avšak učenie sa prináša so sebou aj bariéry, ktoré vznikajú z externého, ale aj interného prostredia. Bariéry vznikajú u vzdelávaného subjektu, vysielajúcej organizácie, organizácie poskytujúcej vzdelávanie, ale aj štátu jeho právnymi úpravami. Bariéry v doslovnom význame slova znamenajú prekážky. Definujeme ich ako faktory, ktoré bránia vykonávat' nejakú činnost', v našom prípade vzdelávanie. Bariéry, ktorým čelia manažéri pri ich vzdelávaní ěasto súvisia s ich rodinnou situáciou, vzdelaním, zamestnaním a veposlednom rade $\mathrm{s}$ ich psychickou kondíciou.

Problematika celoživotného vzdelávania dospelých l’udí je vel'mi komplexná a nie je preto možné definovat' univerzálny a ucelený zoznam bariér, ktoré bránia $\mathrm{v}$ ich rozvoji a vzdelávaní sa. Bariéry, ktoré sú najčastejšie spájané so vzdelávaním dospelých môžeme podla Rabušicovej (2008) rozdelit' do niekol'kých skupín: I. Osobnostné bariéry: nedostatok motivácie, nedostatok sebavedomia, nedôvera v efektívnost', II. Inštitucionálne bariéry: nedostatok informácií, nedostatok vzdelávacích možností, III. Situačné bariéry. Z výskumu Čiháčka (2006) vyplýva, že najvýznamnejšou bariér sú práve finančné prostriedky a finančná náročnost' vzdelávania, kurzov. Barták (2008) bariéry popisuje aj ako dôvody študijných neúspechov. Podl'a neho ide o bariéry kultúry, pracovného prostredia, emočné bariéry, intelektuálne a výrazové bariéry. Mužík (2004) vytvoril pohl'ad na vzdelávanie dospelých: dospelým je nutné pomáhat' a rozvíjat' u nich proces učenia a vzdelávania sa, dospelí sa musia so štúdiom psychicky stotožnit’ a prijat' ho ako súčast' svojho života, dospelí musia prispôsobit' vzdelávaniu sa svoj životný režim a často mu obetovat aj vol'ný čas. Za jednu z bariér možno považovat' (Šipikal \& Parízkova, 2009) nedôveru organizácie $\mathrm{v}$ schopnosti externých vzdelávacích organizácií, ktoré sú považované za samozvaných školitel'ov, ktorí presviedčajú o potrebe vzdelávania a odovzdávania informácii $\mathrm{z}$ oblasti informačno-komunikačných technológií, ktorú považujú v súčasnosti za spôsob rozvoja a posunu organizácií vpred.

\section{Metodológia a použité metódy}

Hlavným ciel'om bolo identifikovat' bariéry, ktoré vplývajú na vzdelávanie manažérov v oblasti IKT. Zároveň sme testovali štatistickú významnost' vplyvu vekovej skupiny a pohlavia na vnímanie jednotlivých bariér. Faktory vek a pohlavie boli určené vo fáze prípravy prieskumu na základe viacerých podnetov získaných zo štruktúrovaných rozhovorov s manažérmi, personalistami (HR), ktorí pozorujú počas svojej praxe disparity medzi jednotlivými skupinami.

Prieskum bol realizovaný prostredníctvom dotazníkovej metódy. Dotazník bol rozdelený na dve sekcie, pričom prvá obsahuje 11 uzatvorených otázok. V štyroch otázkach bola možnost' výberu viacerých odpovedí. $\mathrm{V}$ druhej sekcií respondenti hodnotili 20 bariér podl’a toho, či daný faktor považujú za bariéru vo vzdelávaní. Odpovede, vnímanie bariér, využívanie jednotlivých nástrojov vo vzt’ahu $\mathrm{k}$ respondentom bolo realizované samohodnotením, kde sme zväčša využívali Likertovu škálu.

Pri vytváraní zoznamu bariér sme čerpali poznatky z viacerých literárnych zdrojov domácich i zahraničných autorov. Základným a zároveň východiskovým bodom bola 
analýza dostupných zdrojov zaoberajúcich sa touto problematikou, predovšetkým výskumov realizovaných v zahraničí. Následne sme realizovali štruktúrované rozhovory pre účely prieskumu a v neposlednej rade sme konzultovali možné bariéry s manažérmi oslovených spoločností. Štruktúrované rozhovory boli realizované so spolupracujúcimi organizáciami, partnermi ktoré sa podiel'ajú na realizovaní viacerých prieskumov našej univerzity. S týmito organizáciami sme komunikovali aj počas tvorby dotazník aj pri analýze výsledkov prieskumu.

Jednotlivé bariéry hodnotili respondenti na škále od 1 - silne nesúhlasím, som o tom presvedčený do 6 - silne súhlasím, som o tom presvedčený, podla toho, či daný faktor považovali za bariéru vo vzdelávaní.

V tabul'ke číslo 1 uvádzame pre lepší prehl'ad zoznam jednotlivých bariér aj z ich označeniami, ktoré d’alej využívame vo vyhodnocovacích tabul'kách.

\begin{tabular}{|l|l|}
\hline \multicolumn{2}{|l|}{ Indikátor } \\
\hline B1 & strach \\
\hline B2 & slabá motivácia \\
\hline B3 & odpor k zmenám \\
\hline B4 & neschopnost' učit' sa (chýbajúce zručnosti alebo vedomosti) \\
\hline B5 & nedostatočná informovanost'o možnostiach vzdelávania \\
\hline B6 & vzdelávanie na základe príkazu nadriadeného \\
\hline B7 & nízka návratnost' vynaloženého úsilia \\
\hline B8 & obava so zvýšenia pracovných úloh a nárokov v dôsledku nových vedomostí \\
\hline B9 & nedostatok času na vzdelávanie popri d’alších aktivitách v práci \\
\hline B10 & nedostatok času na vzdelávanie sa mimo práce \\
\hline B11 & nedostatok financií na vzdelávanie na strane respondentov \\
\hline B12 & nedostatok financií na vzdelávanie na strane spoločnosti \\
\hline B13 & atmosféra v podniku degradujúca vzdelávanie \\
\hline B14 & vzdelávanie sa nie je zo strany spoločnosti odmeňované \\
\hline B15 & vzdelávanie sa nie je zo strany spoločnosti uznávané \\
\hline B16 & podniková kultúra nepodporuje vzdelávanie sa \\
\hline B17 & podniková kultúra nepodporuje zmenu \\
\hline B18 & organizačná štruktúra \\
\hline B19 & slabá ponuka a nízka kvalita vzdelávacích kurzov \\
\hline B20 & necitlivý prístup externého školitela \\
\hline
\end{tabular}

$$
\text { Tab. č.: } 1 \text { Analyzované bariéry (Vlastné spracovanie) }
$$

Bariéry následne môžeme rozčlenit' do troch hlavných kategórií, podl'a toho, na koho strane vznikajú:

1. Osobnostné - B1 strach, B2 slabá motivácia, B3 odpor k zmenám, B4 neschopnost' učit' sa (chýbajúce zručnosti alebo vedomosti), B5 nedostatočná informovanost' o možnostiach vzdelávania, B6 vzdelávanie na základe príkazu nadriadeného, B7 nízka návratnost' vynaloženého úsilia, B8 obava so zvýšenia pracovných úloh a nárokov v dôsledku nových vedomostí, B9 nedostatok času na vzdelávanie popri d’alších aktivitách v práci, B10 nedostatok času na vzdelávanie sa mimo práce. 
2. Finančné - B11 - nedostatok financií na vzdelávanie na Vašej strane, B12 nedostatok financií na vzdelávanie na strane spoločnosti.

3. Inštitucionálne - B13 - atmosféra v podniku degradujúca vzdelávanie, B14 vzdelávanie sa nie je zo strany spoločnosti odmeňované, B15 vzdelávanie sa nie je zo strany spoločnosti uznávané, B16 podniková kultúra nepodporuje vzdelávanie sa, B17 podniková kultúra nepodporuje zmenu, B18 organizačná štruktúra, B19 slabá ponuka a nízka kvalita vzdelávacích kurzov, B20 necitlivý prístup externého školitel'a.

Výsledky hodnotenia významnosti jednotlivých bariér sme analyzovali podl’a pohlavia a veku respondentov. Pri vyhodnocovaní sme využívali štatistickú analýzu dát, parametrické a neparametrické testy. Manažérov sme podl'a veku rozdelili do piatich vekových skupín nasledovne: 1. 18-25 rokov, 2. 26-30 rokov, 3. 31-35 rokov, 4. 36-40 rokov a 5.41 a viac rokov.

Prieskumu sa zúčastnilo spolu 85 respondentov. $Z$ celkové počtu respondentov bolo $36 \%$ mužov a $64 \%$ žien. Túto výraznú prevahu ženského pohlavia v spoločnosti spôsobuje fakt, že na pozíciách prvostupňových manažérov a manažérov strednej úrovne sú väššinou ženy a vrcholové manažérske pozície zastávajú prevažne muži.

Respondentov sme podla veku rozdelili do 5 skupín. Najväčšiu skupinu respondentov tvorili manažéri v rozmedzí od 26-30 rokov - $36 \%$, najmenšiu skupinu respondenti vo veku 41 a viac rokov $-8 \%$. Ostatné vekové skupiny boli zastúpené nasledovne - 18-25 rokov $24 \%, 31-35$ rokov $16 \%, 36-40$ rokov $16 \%$. Čo sa týka vzdelania respondentov, úplné stredné všeobecné vzdelanie s maturitou malo $28 \%$, vysokoškolské vzdelanie I. stupňa malo $8 \%$, vysokoškolské vzdelanie II. stupňa malo $60 \%$ a vysokoškolské vzdelanie III. stupňa malo $4 \%$ respondentov. $Z$ údajov vyplýva, že najviac respondentov disponuje vysokoškolským vzdelaním II. stupňa, čo považujeme za primerané vzdelanie pre vykonávanie manažérskej pozície. Zároveň takmer jedna tretina respondentov dosiahlo úplné stredoškolské vzdelanie s maturitou, čo je spôsobené vel'kým počtom prvostupňových manažérov. Spoločnost' na tieto pozície nemá podmienku ukončeného vysokoškolského vzdelania, pokial' zamestnanec preukáže dostatočnú schopnost' vykonávat' danú pozíciu aj bez neho.

\section{Výsledky práce}

Všetci opýtaní respondenti označili, že pri svojej práci využívajú internet a e-mail. Vyplýva to $\mathrm{z}$ povahy manažérskej práce $\mathrm{v}$ podmienkach 21 . storočia. Zaujímavým zistením je fakt, že aj v dobe využívania mobilných zariadení, je v rámci spoločnosti stále viac využívaný osobný PC ako notebook. Osobný PC pri svojej práci využíva $72 \%$ respondentov, zatial' čo notebook pri práci využíva $56 \%$ opýtaných. Videokonferenčné systémy sa $\mathrm{v}$ spoločnostiach využívajú najmä pri komunikácí s centrálou, resp. inými pracoviskami. Videokonferenčné systémy umožňujú spoločnostiam, pracoviskám zdiel'at' informácie $\mathrm{s}$ ostatnými krajinami $\mathrm{v}$ reálnom čase, bez nutnosti vycestovania do danej krajiny. Tento druh IKT využíva $28 \%$ respondentov. V rámci tzv. smart zariadení, viac je v spoločnosti využívaný smartfón, ktorý používa pri práci $64 \%$ respondentov, ako tablet, ktorý využíva len $16 \%$ respondentov. 


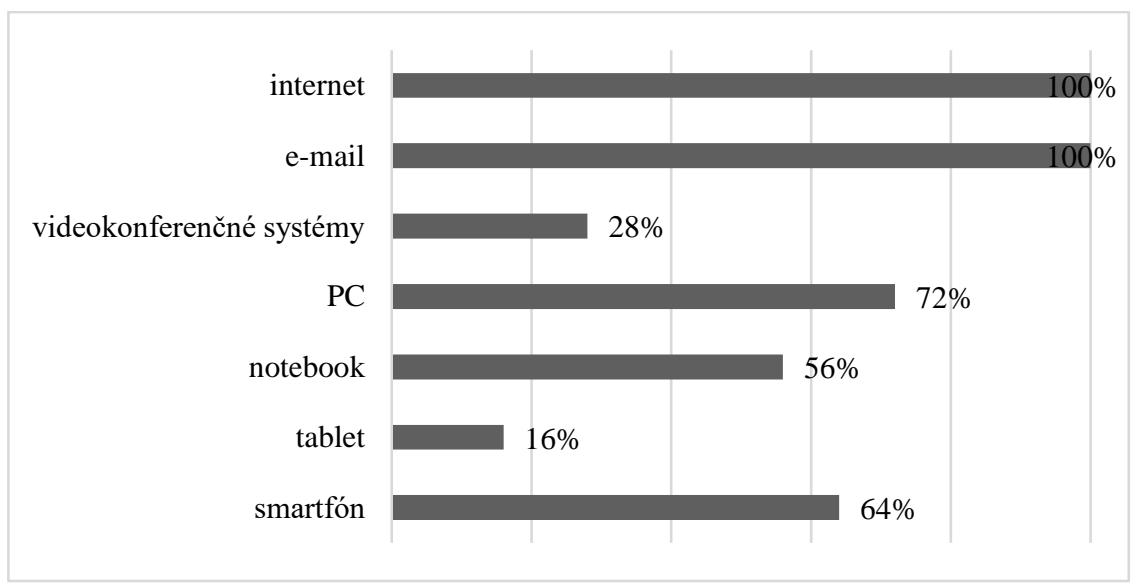

Graf č. 1: Druhy IKT, ktoré respondenti využívajú pri svojej práci (Vlastné spracovanie)

Podiel respondentov, ktorí sa prispôsobujú a učia ovládat' IKT l'ahko tvoril $92 \%$. Zvyšných $8 \%$ tvorili l'udia, ktorí sa prispôsobili a učili ovládat' IKT bud' t'ažko (4 \%), alebo sa ich neučili ovládat' vôbec (4 \%). Pre porovnanie, vo výskume Digitálnej gramotnosti na Slovensku za rok 201560 \% respondentov uviedlo, že sa prispôsobuje a učí ovládat' IKT l'ahko, 17 \% t'ažko a zvyšných 23 \% sa ich neučí ovládat'.

Najväčšie problémy pri práci $\mathrm{s}$ IKT spôsobuje respondentom inštalovanie a nastavovanie základných funkcií programov. Túto možnost' označilo až $44 \%$ manažérov. Vysvetlením môže byt' skutočnost', že pri svojej práci využívajú prevažne sofistikované softvéry, ktoré si pri inštalácií a následnom nastavovaní funkcií vyžadujú odbornejšie znalosti. Používanie externých zariadení a používanie softvéru označilo ako problém zhodne $32 \%$ respondentov. Z toho vyplýva, že síce niektorí manažéri pocitujú t'ažkosti pri inštalovaní a nastavovaní program, ale zároveň z ich následným používaním už problém nemajú. Ďalej $8 \%$ respondentov spôsobuje problém st'ahovanie a odosielanie súborov, 4 \% vyhl'adávanie informácií a služieb na internete a využívanie e-služieb na internete. Využívanie e-mailu, používaním bežných aplikácií a ovládaním smartfónu, resp. tabletu nespôsobuje problém nikomu z opýtaných. 


\section{vyhl'adávanie informácií a služieb na.. e-mail \\ ovládanie PC alebo notebooku využivanie e-služieb na internete používanie bežných aplikácií ovládanie smartfónu alebo tabletu používanie externých zariadení st'ahovanie a odosielanie používanie softvéru} inštalovanie a nastavovanie funkcií.

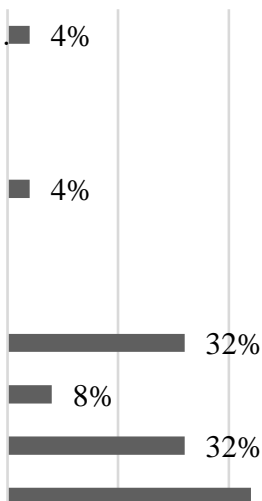

$44 \%$

Graf č. 2: Ktoré aktivity spôsobujú respondentom problémy pri využivaní IKT (Vlastné spracovanie)

V práci sa vzdeláva a absolvuje školenia $44 \%$ respondentov. Ich podiel je menší ako podiel manažérov, ktorí sa v práci nevzdelávajú a nezúčastňujú školení - $56 \%$. Táto skutočnost' má dva dôvody. Prvým z nich je zaneprázdnenost' a vyt'aženost' manažérov. Popri svojich časovo náročných aktivitách a úlohách $\mathrm{v}$ práci im nezostáva čas na d’alší rozvoj ich schopností a zručností. Druhý dôvod predstavuje väčší počet prvostupňových manažérov a manažérov strednej úrovne, ktorí častokrát využívajú pri svojej práci len štandardné kancelárske aplikácie, ako je napríklad kancelársky balík Microsoft Office. Vedenie spoločnosti tak častokrát nepocituje potrebu d'alej vzdelávat' svojich manažérov v oblasti IKT, lebo majú pocit, že nadobudnuté poznatky by v svojej práci nevyužívali a investícia spoločnosti do ich vzdelávania by sa nenavrátila. Vo svojom volnom čase sa vzdeláva až $64 \%$ respondentov. $Z$ toho vyplýva, že aj manažéri, ktorí sa vo svojej práci nevzdelávajú, $v$ skutočnosti majú záujem sa d’alej rozvíjat'. $Z$ vyššie uvedených dôvodov však toto vzdelávanie a školenia absolvujú mimo pracovnú dobu.

V nadväznosti na predchádzajúcu otázku, až $92 \%$ manažérov uviedlo, že vzdelávanie realizuje formou samovzdelávania. $Z$ nášho pohl'adu to predstavuje určitú spojitost's tým, že aj podnet na vzdelávanie dáva samým sebe $88 \%$ manažérov. Druhá najčastejšie využívaná forma vzdelávania je e-learning, ktorý praktizuje 40 \% respondentov. Približne jedna tretina manažérov taktiež využíva a zúčastňuje sa workshopov a prednášok. Koučing a kurzy využíva $24 \%$ opýtaných. Seminár, tréning a štúdium doporučenej literatúry praktizuje $16 \%$ respondentov. Najmenej využívanou formou sú certifikácie, ktoré absolvovalo len $8 \%$. 


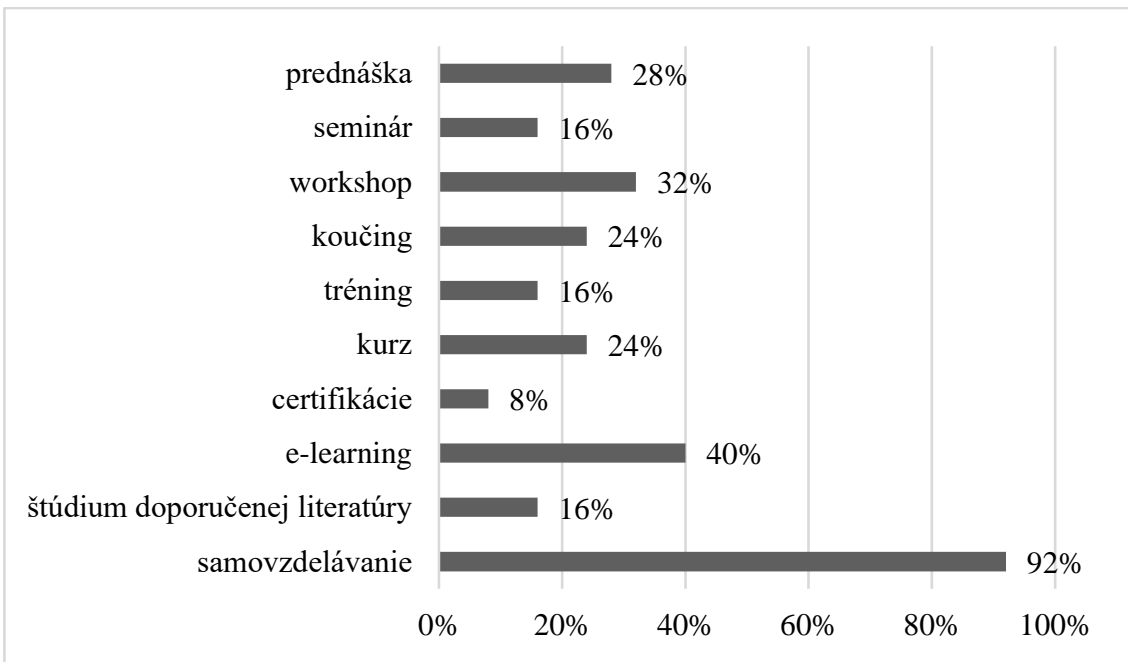

Graf 3: Formy vzdelávania, ktoré respondenti využili/využívajú (Vlastné spracovanie)

\section{1 Hodnotenie významnosti jednotlivých bariér podl’a veku}

Za najvýznamnejšiu bariéru si respondenti zvolili bariéru B10 - nedostatok času na vzdelávanie sa mimo práce, ktorej priemerná hodnota je 4,56 b pri štandardnej odchýlke 1,08 b. Najvyššiu hodnotu 5,00 b dosiahla bariéra B10 vo vekovej skupine č. $5-41$ a viac rokov a najnižšiu hodnotu 4,25 b vo vekovej skupine č. $3-31$ až 35 rokov. Druhú najvýznamnejšiu bariéru predstavuje bariéra B9 - nedostatok času na vzdelávanie popri d’alších aktivitách $\mathrm{v}$ práci, ktorej priemerná hodnota je 4,24 b pri štandardnej odchýlke 0,97 b. Najvyššiu hodnotu 5,00 b dosiahla bariéra B9 vo vekovej skupine č. $5-41$ a viac rokov a najnižšiu hodnotu 3,5 b vo vekovej skupine č. $3-31$ až 35 rokov. Tret’ou najvýznamnejšou bariérou je bariéra B11 - nedostatok financií na vzdelávanie na strane respondentov, ktorej priemerná hodnota je $4,00 \mathrm{~b}$ pri štandardnej odchýlke $1,35 \mathrm{~b}$. Najvyššiu hodnotu 4,75 b dosiahla bariéra B11 vo vekovej skupine č. $4-36$ až 40 rokov a najnižšiu hodnotu $2,50 \mathrm{~b}$ vo vekovej skupine č. $5-41$ a viac rokov. Ako najmenej významnú bariéru respondenti označili bariéru B1 - strach, ktorej priemerná hodnota je 1,76 b pri štandardnej odchýlke 0,78 b. Najvyššiu hodnotu 2,00 b dosiahla bariéra B1 zhodne vo vekových skupinách č. $5-41$ a viac rokov a č. $2-26$ až 30 rokov, a najnižšiu hodnotu 1,25 b vo vekovej skupine č. $4-36$ až 40 rokov.

\begin{tabular}{|c|c|c|c|c|c|c|c|}
\hline \multirow[b]{2}{*}{ Indikátor } & \multicolumn{5}{|c|}{ Veková skupina } & \multirow{2}{*}{ M } & \multirow{2}{*}{ STDEV } \\
\hline & 1. & 2. & 3. & 4. & 5. & & \\
\hline B1 & 1,67 & 2,00 & 1,75 & 1,25 & 2,00 & 1,76 & $\mathbf{0 , 7 8}$ \\
\hline B2 & 2,67 & 4,11 & 3,25 & 3,00 & 3,50 & 3,40 & 1,29 \\
\hline B3 & 1,50 & 2,78 & 2,50 & 2,75 & 3,00 & 2,44 & 0,96 \\
\hline B4 & 1,17 & 1,89 & 2,50 & 1,75 & 3,00 & 1,88 & 1,24 \\
\hline B5 & 3,67 & 3,11 & 2,25 & 2,75 & 1,50 & 2,92 & 1,12 \\
\hline
\end{tabular}




\begin{tabular}{|l|l|l|l|l|l|l|l|}
\hline B6 & 4,00 & 2,00 & 3,50 & 3,00 & 1,50 & 2,84 & 1,49 \\
\hline B7 & 3,33 & 2,67 & 4,50 & 3,25 & 2,50 & 3,20 & 1,41 \\
\hline B8 & 2,33 & 2,56 & 3,00 & 2,50 & 2,50 & 2,56 & 1,26 \\
\hline B9 & $\mathbf{4 , 0 0}$ & $\mathbf{4 , 4 4}$ & $\mathbf{3 , 5 0}$ & $\mathbf{4 , 5 0}$ & $\mathbf{5 , 0 0}$ & $\mathbf{4 , 2 4}$ & $\mathbf{0 , 9 7}$ \\
\hline B10 & $\mathbf{4 , 6 7}$ & $\mathbf{4 , 5 6}$ & $\mathbf{4 , 2 5}$ & $\mathbf{4 , 5 0}$ & $\mathbf{5 , 0 0}$ & $\mathbf{4 , 5 6}$ & $\mathbf{1 , 0 8}$ \\
\hline B11 & $\mathbf{4 , 3 3}$ & $\mathbf{3 , 6 7}$ & $\mathbf{4 , 2 5}$ & $\mathbf{4 , 7 5}$ & $\mathbf{2 , 5 0}$ & $\mathbf{4 , 0 0}$ & $\mathbf{1 , 3 5}$ \\
\hline B12 & 4,17 & 3,00 & 2,75 & 2,50 & 1,50 & 3,04 & 1,17 \\
\hline B13 & 3,00 & 1,56 & 2,75 & 2,75 & 1,50 & 2,28 & 1,28 \\
\hline B14 & 4,17 & 3,11 & 5,25 & 3,75 & 2,50 & 3,76 & 1,33 \\
\hline B15 & 3,00 & 2,11 & 3,50 & 2,75 & 2,50 & 2,68 & 1,22 \\
\hline B16 & 2,17 & 2,44 & 3,50 & 2,75 & 2,50 & 2,60 & 1,32 \\
\hline B17 & 2,00 & 2,22 & 3,25 & 2,75 & 2,50 & 2,44 & 1,23 \\
\hline B18 & 3,17 & 2,44 & 3,50 & 2,75 & 2,50 & 2,84 & 1,40 \\
\hline B19 & 3,33 & 3,22 & 2,75 & 3,25 & 2,50 & 3,12 & 1,30 \\
\hline B20 & 2,33 & 2,11 & 2,00 & 3,50 & 1,50 & 2,32 & 1,28 \\
\hline
\end{tabular}

Tab. č. 2: Hodnotenie významnosti jednotlivých bariér podla vekových skupín (Vlastné spracovanie)

Po analýze významnosti jednotlivých bariér v závislosti od vekovej skupiny, sme testovali štatistickú významnost' vplyvu vekových skupín na jednotlivé bariéry, na hladine významnosti $\alpha=0,05$. Väčšina dát spíňali podmienku normálneho rozdelenia dát $p>0,05$, okrem bariéry B6 - vzdelávanie na základe príkazu nadriadeného, B17 - podniková kultúra nepodporuje zmenu a B18 - organizačná štruktúra. Pri testovaní normálne rozdelených dát sme následne využili metódu Anova. Štatisticky významný vplyv vekovej skupiny sa nám potvrdil u dvoch bariér, a to B3 - odpor k zmenám $\mathrm{p}=0,042$, B12 - nedostatok financií na vzdelávanie na strane spoločnosti $\mathrm{p}=0,023$. Vplyv vekovej skupiny na vnímanie bariér B6 - vzdelávanie na základe príkazu nadriadeného, B17 - podniková kultúra nepodporuje zmenu a B18 - organizačná štruktúra sme testovali prostredníctvom neparametrického testu Kruskal-Wallis. Štatisticky významný vplyv vekovej skupiny sa potvrdil na bariéru B6 -vzdelávanie na základe príkazu nadriadeného $\mathrm{p}=0,043$.

\section{2 Hodnotenie významnosti jednotlivých bariér podl'a pohlavia}

Za najvýznamnejšiu bariéru si muži zvolili bariéru B10 - nedostatok času na vzdelávanie sa mimo práce, ktorej priemerná hodnota je 4,67 b so štandardnou odchýlkou 1,32 b. Ženy si za najvýznamnejšiu bariéru zvolili zhodne bariéru B10, ktorej priemerná hodnota je 4,50 so štandardnou odchýlkou 0,97 b. Druhú najvýznamnejšiu bariéru pre mužov predstavuje bariéra B9 - nedostatok času na vzdelávanie popri d’alších aktivitách v práci, ktorej priemerná hodnota je 4,33 b so štandardnou odchýlkou 1,00 b. Ženy si ako druhú najvýznamnejšiu bariéru zvolili zhodne bariéru B9 - nedostatok času na vzdelávanie popri d’alších aktivitách v práci, ktorej priemerná hodnota je 4,19 b so štandardnou odchýlkou 0,98 b. Tretou najvýznamnejšou bariérou pre mužov je bariéra B11 nedostatok financií na vzdelávanie na strane respondentov, ktorej priemerná hodnota je 4,00 b so štandardnou odchýlkou 1,66 b. Pre ženy ňou bola zhodne bariéra B11- nedostatok financií na vzdelávanie na strane respondentov, ktorej priemerná hodnota je 4,00 b so 
štandardnou odchýlkou 1,21 b. V rámci troch najvýznamnejších bariér si muži a ženy zvolili rovnaké bariéry a dokonca aj ich rovnaké poradie.

Ako najmenej významnú bariéru muži označili bariéru B1 - strach, ktorej priemerná hodnota je 1,67 b so štandardnou odchýlkou 0,87 b. Ženy si zvolili ako najmenej významnú bariéru B4 - neschopnost' učit' sa (chýbajúce zručnosti alebo vedomosti), ktorej priemerná hodnota je 1,75 b so štandardnou odchýlkou 1,06 b.

\begin{tabular}{|c|c|c|c|c|}
\hline \multirow{3}{*}{ Indikátor } & \multicolumn{4}{|c|}{ Pohlavie } \\
\hline & \multicolumn{2}{|c|}{ Muž } & \multicolumn{2}{|c|}{ Žena } \\
\hline & $\mathbf{M}$ & STDEV & M & STDEV \\
\hline B1 & 1,67 & 0,87 & 1,81 & 0,75 \\
\hline $\mathrm{B} 2$ & 3,22 & 1,39 & 3,50 & 1,26 \\
\hline B3 & 1,89 & 0,93 & 2,75 & 0,86 \\
\hline B4 & 2,11 & 1,54 & 1,75 & 1,06 \\
\hline B5 & 3,00 & 1,66 & 2,88 & 0,72 \\
\hline B6 & 3,78 & 1,79 & 2,31 & 1,01 \\
\hline B7 & 3,78 & 1,72 & 2,88 & 1,48 \\
\hline B8 & 2,33 & 1,12 & 2,69 & 1,35 \\
\hline B9 & 4,33 & 1,00 & 4,19 & $\mathbf{0 , 9 8}$ \\
\hline B10 & 4,67 & 1,32 & 4,50 & $\mathbf{0 , 9 7}$ \\
\hline B11 & 4,00 & 1,66 & 4,00 & 1,21 \\
\hline B12 & 3,33 & 1,66 & 2,88 & 0,81 \\
\hline B13 & 2,78 & 1,72 & 2,00 & 0,89 \\
\hline B14 & 3,67 & 1,73 & 3,81 & 1,11 \\
\hline B15 & 2,78 & 1,20 & 2,63 & 1,26 \\
\hline B16 & 2,33 & 1,32 & 2,75 & 1,34 \\
\hline B17 & 2,11 & 1,05 & 2,63 & 1,31 \\
\hline B18 & 2,89 & 1,83 & 2,81 & 1,17 \\
\hline B19 & 3,22 & 1,64 & 3,06 & 1,12 \\
\hline $\mathrm{B} 20$ & 2,44 & 1,67 & 2,25 & 1,06 \\
\hline
\end{tabular}

Tab. č. 3: Hodnotenie významnosti jednotlivých bariér podla pohlavia (Vlastné spracovanie)

Po kvantifikácii významnosti jednotlivých bariér podl'a pohlavia, sme testovali štatisticky významný vplyv pohladia na jednotlivé bariéry. Väčšina dát bola normálne rozdelená $\mathrm{p}>0,05$. Štatistickú významnost' sme testovali pomocou parametrického Ttestu. Štatisticky významný vplyv pohlavia sa potvrdil u bariéry B3 - odpor k zmenám p $=0,028$. Dáta, ktoré nespĺn̆ali podmienku normálneho rozdelenia dát B5 - nedostatočná informovanost' o možnostiach vzdelávania, B6 - vzdelávanie na základe príkazu nadriadeného, B12 - nedostatok financií na vzdelávanie na strane spoločnosti, B13 atmosféra v podniku degradujúca vzdelávanie sme testovali prostredníctvom neparametrického Mann-Whitney testu. Štatistická významnost' sa potvrdila u bariéry B6 - vzdelávanie na základe príkazu nadriadeného $\mathrm{p}=0,015$. 


\section{Diskusia}

Z výsledkov nami realizovaného prieskumu vyplýva, že manažéri pri svojej práci aktívne využívajú IKT, ktoré im vo vel'a smeroch ul'ahčili realizovanie pracovných úloh. Ako príklad môžeme uviest' videokonferenčné systémy, pomocou ktorých komunikujú medzi sebou manažéri jednotlivých krajín. Z výsledkov sme zároveň dospeli k záveru, že manažéri si uvedomujú dôležitost' vzdelávat' sa v oblasti IKT a zväčša patria medzi čast' spoločnosti, ktorá sa učí ovládat' a prispôsobuje sa IKT l'ahko.

Ako najvýznamnejšiu bariéru respondenti zvolili nedostatok času na vzdelávanie sa mimo práce. Avšak pri otázke, či sa manažéri vzdelávajú vo svojom vol'nom čase, väčšina z nich uviedla odpoved' áno. Z toho usudzujeme, že problémom bude najmä zlý time management na strane zamestnancov a ich možné pret’ažovanie na strane spoločnosti. Pre odstránenie tejto bariéry by bolo vhodné realizovat' pre zamestnancov workshopy, resp. školenia na tému time managementu. Vhodná by bola aj podpora tzv. work-life balance zamestnancov, čo $\mathrm{v}$ praxi znamená podporu zosúladenia pracovného a súkromného života zamestnancov. Táto aktivita má za následok zvýšenie spokojnosti a lojálnosti zamestnancov, a dáva im zároveň väčší priestor na ich osobný rozvoj v oblastiach, ktoré ich zaujímajú. V rámci nášho dotazníkového prieskumu takmer všetci manažéri označili, že využívajú samovzdelávanie ako formu vzdelávania. Z psychologického hl'adiska vel'a l'udí uprednostňuje práve samovzdelávanie pred ostatnými formami vzdelávania, lebo sa pri ňom cítia komfortnejšie a zároveň si sami môžu určovat' tempo a obsah vzdelávania. Túto formu vzdelávania je však z nášho pohl'adu lepšie vykonávat' vo svojom vol'nom čase, ked’že podmienky v pracovnom prostredí nie vždy umožňujú jeho realizáciu. V dnešnej dobe prevláda trend tzv. open office kancelárií, kde prostredie môže pôsobit' naozaj rušivo a t'ažko sa manažér pri ňom sústredí na efektívne samovzdelávanie. To nám potvrdili aj manažéri pri osobných rozhovoroch. $\mathrm{Z}$ týchto dôvodov považujeme za nutné popracovat' na odstránení tejto bariéry a to tak na strane manažérov, ako aj na strane spoločnosti.

Za druhú najvýznamnejšiu bariéru si manažéri zvolili nedostatok času na vzdelávanie sa popri práci. Zároveň pri otázke, či sa manažéri vzdelávajú v práci, väčšina uviedla odpoved' nie. Dôležité je prehodnotit' možnosti vzdelávania sa zamestnancov a zaradit' vzdelávanie medzi ich pracovné aktivity. Nemusí sa nutne jednat' o časovo náročné a zdíhavé aktivity, ktoré by mohli negatívne ovplyvnit' spĺňanie termínov ich úloh. Stále populárnejšou metódou vzdelávania sa stáva v posledných rokoch e-learning. Je to metóda, kedy sa vzdeláva jednotlivec prostredníctvom PC. Túto metódu si zároveň zvolili aj manažéri $\mathrm{v}$ dotazníku ako najviac využívanú. Na túto aktivitu by mohli mat' manažéri vyčlenenú pol hodinu denne v rámci ich pracovného času, čo pri 8 hodinovom pracovnom úväzku predstavuje len $6,25 \%$ z celkového pracovného času.

Ako tretiu najvýznamnejšiu bariéru vo vzdelávaní si manažéri zvolili nedostatok financií na ich strane. Sme toho názoru, že vzdelávanie patrí medzi tie veci v živote, kde sa rozhodne oplatí investovat' a táto investícia sa aj vo väčšine prípadov človeku vráti, či už vo forme kariérneho rastu alebo lepšieho finančného ohodnotenia. Preto je na mieste túto bariéru prehodnotit' a zamysliet' sa nad tým, či ako človek neinvestuje svoje úspory do menej potrebných vecí, ako sú napríklad hmotné veci. Tu sa naskytá príležitost' analyzovat' svoje mesačné výdavky a optimalizovat' ich úroveň tak, aby sa človek mohol venovat' aj svojmu osobnému rozvoju, ktorý je v živote naozaj dôležitý. V dnešnej dobe taktiež existuje mnoho bezplatných kurzov na podporu vzdelávania, ktoré prevádzkujú 
štátne inštitúcie, ale aj súkromné spoločnosti. Ako príklad môžeme uviest' vzdelávací program Digitálna garáž od spoločnosti Google, ktorý je zameraný na digitálne zručnosti a online marketing. Kurz prebieha online prostredníctvom internetu a po jeho absolvovaní je možné získat' certifikát. Čiháček (2006) považuje tiež túto bariéru za jednu z najvýznamnejších bariér vo vzdelávaní dospelých.

Komparácia výsledkov nášho prieskumu je determinovaná ciel'ovou skupinou, nakol'ko náš prieskum potvrdil za najvýznamnejšiu bariéru práce nedostatok času, ktorý je podla nášho názoru ovplyvnený povahou práce manažérov. Dosial' nebol realizovaný v Slovenskej republike prieskum zameraný na bariéry vo vzdelávaní manažérov v oblasti informačno-komunikačných technológií. Stotožňujeme so závermi, tvrdeniami a postojmi Mužíka (2004), Čiháčka (2006), Rabušicovej (2008) o významnosti jednotlivých bariér. Manažéri patria $\mathrm{k}$ skupine dospelých, ktorí sú súčast'ou celoživotného vzdelávania, avšak významnost' bariér sa odlišuje od povahy ich práce, profesie. Práve špecifikum tejto skupiny respondentov zmenilo poradie významnosti bariér. Preto konštatujeme, že ako východisková literatúra a prieskumy týchto autorov boli vhodným zdrojovým materiálom.

\section{Záver}

Vzdelávanie je náročný a zdíhavý proces, ktorý si vydržuje určitý čas a osobný postoj vzdelávaného, tieto faktory nie je možné obíst' a ani vynechat'. Preto je dôležité vyzdvihnút' hodnotu vzdelávania a možné budúce prínosy pre osobu, spoločnost' ktorej sa týka. Nami realizovaný prieskum bol zameraný na identifikáciu bariér vo vzdelávaní manažérov v oblasti IKT. Zaujímavým zistením je fakt, že na poslednom mieste a ako najmenšiu bariéru si respondenti zvolili práve strach zo vzdelávania. Vypovedá to o tom, že manažéri sú otvorení vzdelávaniu sa. Odôvodnením môže byt' aj skutočnost', že takmer všetci manažéri označili, že sa prispôsobujú a učia ovládat' IKT l'ahko. Manažéri by prirodzene mali byt' schopní pružne reagovat' na zmeny a prispôsobovat sa im. $\mathrm{V}$ dnešnej digitálnej ére sú to práve IKT, ktoré ovplyvňujú a menia podmienky na trhu. Zároveň sme identifikovali rozdiely vnímania bariér na základe vekových skupín. Významnost' jednotlivých bariér rastie vekom respondentov, manažérov. Vyššie hodnoty významnosti bariér označili predovšetkým manažéri vekovej skupiny nad 41 rokov. Je to prirodzené vzhl'adom na ich vek, lebo za čias ich štúdia boli počítače a IKT len na začiatku vývoja. Znamená to, že sa v zásade postupným zmenám a rýchlemu rozvoju IKT museli prispôsobit' bez toho, aby mali nejaký základ, ktorý môžu d’alej systematicky rozvíjat'. Najmenej významne vnímali bariéry predovšetkým manažéri vo veku 31 až 35 rokov. Túto skupinu tvoria manažéri, ktorí sú $\mathrm{v}$ najproduktívnejšom veku a zároveň sa v našom prieskume ukázali aj ako najviac flexibilní. Majú už dostatočnú prax v práci, ale zároveň cítia potrebu sa d'alej rozvíjat', lebo majú ešte kam kariérne rást'. Štatisticky významný vplyv vekovej skupiny sa nám potvrdil u dvoch bariér, a to pri odpore k zmenám a nedostatku financií na vzdelávanie na strane spoločnosti. Pri analyzovaní výsledkov vzhl’adom na pohlavie manažérov sa výsledky líšili len v minimálnej miere, z čoho usudzujeme, že bariéry vo vzdelávaní sú vnímané manažérmi takmer rovnako, bez rozdielu na pohlavie. Štatisticky významný vplyv pohlavia sa potvrdil u bariéry odpor $\mathrm{k}$ zmenám a rovnako $\mathrm{v}$ prípade bariéry vzdelávanie na základe príkazu nadriadeného. 


\section{Pod'akovanie}

Príspevok bol podporený v rámci projektu na Ekonomickej univerzite v Bratislave č. I-17$109-00$.

\section{Použitá literatúra}

Barták, J. (2008). Jak vzdělávat dospělé. 1.vyd. Praha : Alfa, 2008,197 s. ISBN 978-8087197-12-7.

Boyatzis, R. E. (1982). The Competent Manager: A Model for Effective Performance. New York : John Wiley \& Sons, p. 12. ISBN 978-0-471-09031-1.

Bassellier, G. (2001). Information technology competence of business managers: A definition and research model. In Journal of management information systems. p. 171. 17(4). ISSN 0742-1222.

Brown, C.V. \& Magil, S.L. (1994). Alignment of the IS functions with the enterprise: toward a model of antecedents. In MIS Quarterly. p. 371. 18(4). ISSN 0276-7783

Čiháček, V. (2006). Bariéry účasti dospélých v kurzech celoživotního vzdělávání- „penize jsou až na prvním mistě “. Sborník prací filozofické fakulty brněnské univerzity

Studia Minora Facultatis philosophicae Universitatis Brunensis. 2006, roč. 54, č. U11. ISBN: 80-210-4143-9.

Mužík, J. (2004). Androdidaktika. 2. vydanie. Praha : ASPI, 2004. 146 p. ISBN 80-7357045-9.

Rabušicová, M. \& Rabušic, L. (2008). Učime se po celý život?: o vzděláváni dospělých v České republice. 1 vydanie. Brno : Masarykova univerzita, 2008. p. 50-106. ISBN 97880-210-4779-2.

Reich, B.H. \& Benbasat, I. (2000). Factors that influence the social dimension of alignment between business and information techonology objectives. In MIS Quarterly. p. 81.24 (1). DOI 10.2307/3250980

Šipikal, M. \& Parízková, J. (2009). Učiace sa regióny. Bratislava : Ekonóm, 2009. p. 42. ISBN 978-80-225-2732-3. 